\title{
The Biophobia of Satan’s Bunny: The Influence of Horror Films in Contemporary Brazilian Literature
}

\author{
Gabriela Lopes Vasconcellos de Andrade \\ Universidade Federal da Bahia-Fulbright, Salvador, Brazil
}

\begin{abstract}
In the course, FTV 201A: MEDIA INDUSTRIES and CULTURES of PRODUCTION: FOUNDATIONS, we discussed how to think the philosophy and thoughts that surround people who produce and work in the culture of production and media. That way, the purpose of this work is to think the use of post-horror label as a marketing strategy in the context of Brazilian contemporary literature and cinema. For that, I map the profile of three Brazilian writers: Santiago Nazarian, Antonio Xerxenesky, and Raphael Montes. They are published now by Companhia das Letras, the largest publisher in Brazil, which has an extensive work with the horror literature, having the exclusivity of Stephen King's books. In addition, all three circulate differently in the media space, standing between an acceptance of academic criticism and the prestige of large-scale consumer audiences. I analyzed what are the writer strategies to construct their image and establish themselves in the literary market using the Post-horror label and its relation with the production company, RT Features, which is financing them. In the end, I did a critical analyzes of the post-horror label as a transmedia strategy to construct an author’s name.

Keywords: post-horror, RT features, Brazilian literature
\end{abstract}

\section{Cannibalism and Biophobia: Not Only in the Movies, the "Post-Horror" Wave in Contemporary Brazilian Literature}

\section{The Context of Brazilian Literature and Cinema}

Brazilian literature was constructedby through literary historiographies. Contemporaneously, especially after twentieth-century theoretical currents such as structuralism and post-structuralism, history is accepted as a subjective perspective created by people who have the economic and political power, making minorities invisible. In Brazil, literary historiographies emerged based on the positivist method of the nineteenth century, from an arbitrary selection of what would supposedly represent the best of the country, a process focused on trying to create homogeneity of themes linked to the construction of its nationality.

With Brazil's independence, the economic elite tried to forge a national identity through the literature, using it as an arbitrary and elitist parameter of what was imagined as a universal quality. That is why, in the nineteenth century, José de Alencar was elected as the greatest name of Brazilian literature for creating the myth of the good, savage Indian figure, which was submissive to the European order. By portraying the dilemmas of the urban

Gabriela Lopes Vasconcellos de Andrade, Ph.D. student, Department of Literatura e Cultura, Universidade Federal da Bahia-Fulbright. 
center bourgeoisie as the main population of Brazil, this process excluded black people from this nationalist project. Literary historiographies provide a space for concrete elaboration of the canon, which is a methodological selection discourse of arbitrary choices that cultural elites naturalize.

In order to question the process of canonization of literary works, Roberto Reis (1992) says that it is necessary to denounce the mechanisms of power. The author argues that all knowledge is produced from historical and ideological conditions and all interpretation is based on an institutional social position. In order to question a literary text, product of writing and knowledge, it is necessary to contextualize its historical circumstances and what the literary character means. High-culture vs. popular culture/mass discourse has been constructed under this paradigm, which disparages one over the other and attempts to build a national identity through the idea of a universal model.

Eneida Maria de Souza (2002) discusses the positioning of the literary scenery in Brazil. Faced with the breakdown of the hegemony of canonical literary discourse, caused by the new theoretical paradigms arising from Cultural Studies and Post-structuralism, traditional criticism faults the lack of criteria when it comes to evaluating the text and, above all else, leveling it by the reception. Quality criteria would be forgotten in favor of the easy consumption of the literary text and the taste of the ordinary reader, little concerned with the aesthetic plane and the value of literature. This positioning of criticism acts as a form of resistance to the democratization of discourses by Cultural Studies, and to the power of the market and theconsumerist culture of bestsellers. Beyond the discussion of the aesthetic value and erasure of socially marginalized voices (women, blacks, non-binary subjects, Indians, gays), all this discussion is based on the processes of democratization of culture, loss of privileged places of knowledge and of market interests. After all, the positioning of part of the criticism happens as a form of resistance to the market power, which, often, by turning to the serialization of the same, prevents the visibility and publication of other forms of literature.

Santiago Nazarian (2017a), one of the authors interviewed for this research, wrote an article for A Folha de São Paulo, the main printed newspaper in Brazil. The text maps the source of income of Brazilian writers. The average circulation of a contemporary literature book is three thousand copies, and for the cover value of each book sold, the artist only receives $10 \%$. Nazarian calculates, with the average price of thirty-five reais per capita and the standard print run of three thousand copies, that a writer who is able to sell all those copies in two years will have an average income of less than five hundred reais per month. The author uses this means to begin an argument that it is impossible for most contemporary artists to make a living through literature alone.

Although academic and university critics have sought a commitment in regards to the democratization of discourses as an attempt to study and give legitimacy to new forms of writing, the literary market continues to be invested on the same things. Arnaldo Cortina (2014) seeks to draw, from the most sold books over 44 years, what interests the Brazilian reader and what it says about them. Cortina says that during the period from 1966 to 2010, $58 \%$ of the most read books were self-help ones and the other $42 \%$ were divided into five categories: memory (17\%), action (5\%), humor (cadê a porcentagem?), fantasy (5\%), philosophical (5\%) and police (5\%). Looking at the list of best-selling books from 2010 to 2017, published by online newspaper Nexo, you can see the prevalence of self-help productions, which make up to $70 \%$ of the list. The producers of Brazilian contemporary fiction literature do not appear in the 25 books listed, proving that yes, it is a literature for niches. Although these are diverse, they represent a small part of the universe of millions of copies. 
Thinking about the context of cinema, the first official theaterswere inaugurated between 1907 and 1910, in São Paulo and Rio de Janeiro, respectively, with the consolidation of electric energy in these two cities. The first Brazilian productions were shown in those rooms and all of them were short films with a journalistic narrative about crimes that shocked the urban centers. However, the Brazilian production could not grow without investment and, as Carlos Alberto de Souza (2007) states in the article Roots of Brazilian Cinema, it began the exclusive exhibitions of American films of Vitagrapha in 1911, which came with an industrial aesthetic, completely different from the first Brazilian cinematographic experiences.

The film market in Brazil began to be organized by a foreign demand, which was formed by a group of industrialists and bankers, owners of political and financial capital, to take care of the distribution and exhibition of American, French and Italian films. Souza (2007) points out the fact that the economic elite, from the old political oligarchies, always embraced foreign interests in all areas of the economic structure, and when it came to cinema, it was no different. To them, only films with the same perfection of foreign factories would be accepted. At the same time, there was the mystification of foreign stars and an entire advertising market linked to the production of this cinema, which during World War II banned French, German and Italian films, giving exclusivity to North American.

In the same period, in São Paulo, another phenomenon occurred. Souza says that, due to the massive penetration of European and Japanese immigrants, many artistic activities began to emerge, among them various amateur theater groups. In 1915, the Italian theater company of Alberto Capozzi joined the Brazilian filmmaker Antônio Campos to produce fictional cinema. Inspired by the commercial success of novels, which generated the greatest names of Brazilian literature, they began to adapt Brazilian literary works linked to the nationalism themes to characterize the cinema produced in Brazil.

The predominance of North American foreign cinema and national production focused on the discourse of nationality, even criticizing the order and maintenance of inequality, have become, until today, characteristics of the national cinematographic market. The issue of nationalism was consolidated with the creation of Cineart, a vehicle for public disclosure and state sponsorship of cinema, createdduringGetulio Vargas' government. Ismail Xavier (2001) discusses how there is a maintenance of the idea of talking about the nation in Brazilian cinema, but mainly in the 50's, and Glauber Rocha's Cinema Novo. The author differentiates the project proposal from GlauberRocha. However, as Xavier states, it is still linked to a historical process of the construction of art based on literature and Brazilian identity.

Xavier contextualizes that, with the military dictatorship, the foreign marketwas closed and, at the same time, there was a process of censorship of the productions that spoke about the oppression of the people and about social inequality, as in the case of Cinema Novo. Embrafilme was created during this period, which intervened and financed national cinema in a centralized way, linked to an economic elite and defending the values of an apathetic, extreme right bourgeoisie who exiled and tortured artists who questioned the coup d'état. Arthur Autran (2009) maps the Brazilian audiovisual market after the military dictatorship. In 1990, the Embrafilme was closed during the government of the president Fernando Collor de Mello. To the author, the state investment cut was based on a neoliberal agenda, but also as a response to the use of cinema as right wing ideals advertise throughout the period of dictatorship. This was in consonance with Hollywood desires to expand globally. Autran points out that, only in 1993, the Audiovisual Law was approved, which allowed national companies to have tax 
reductions if they invested in national cinema.

By the end of the FHC'sgovernment, ANCINE was created to regulate the cinematographic activity, which was consolidated in the PT government and, based on fiscal incentives, increased the number of films made in Brazil. According to infographics published by Globo newspaperin 2016, in the last 21 years, there was a 921\% increase of the national film productions.

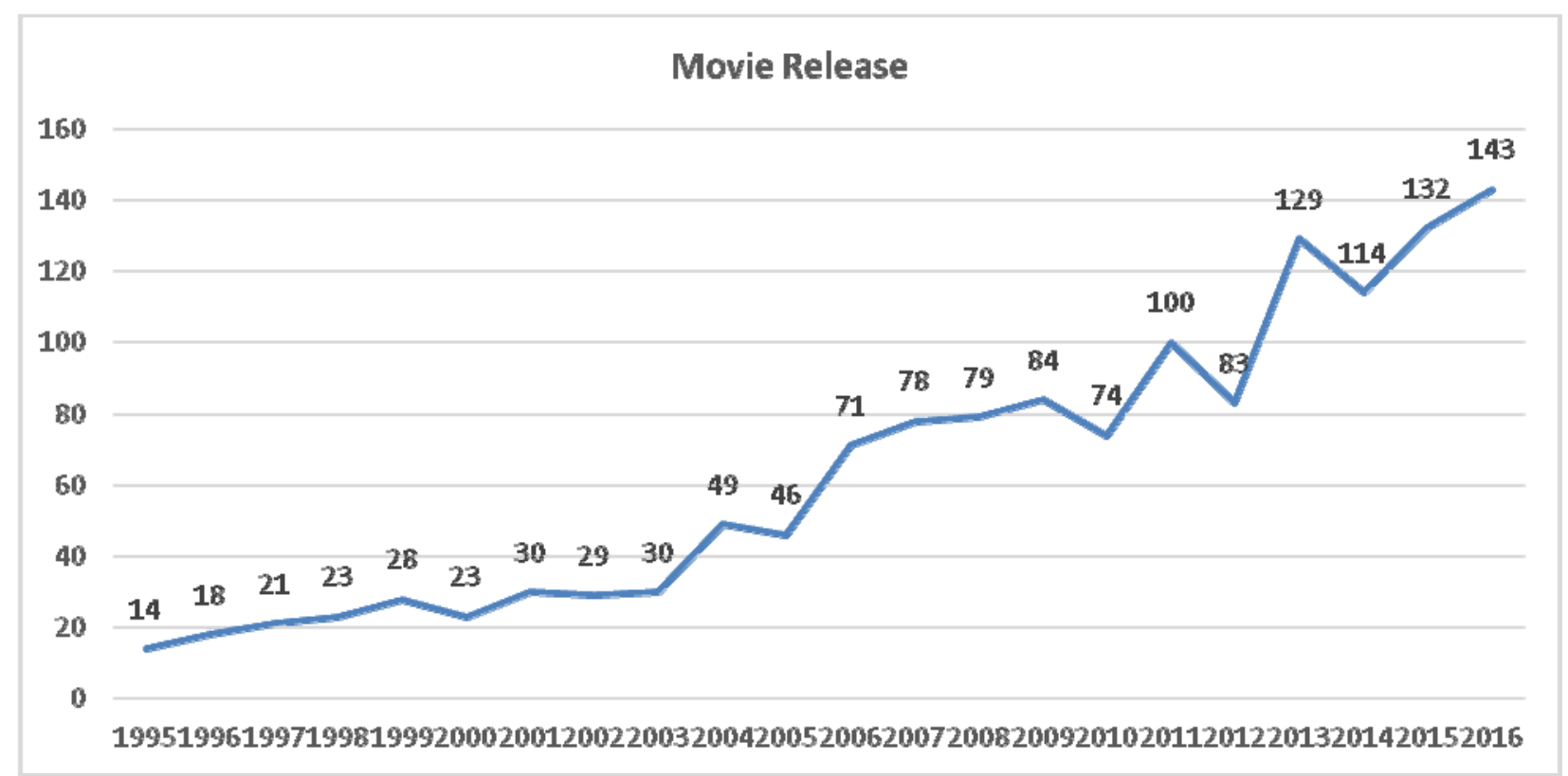

Figure 1. Number of Brazilian Movies Per Year.

This increase was only due to the financing of PT's government and the new audiovisual practices. As Autran asserts, the exhibition and distribution of cinema in Brazil was always linked to foreign conglomerates and, in the 1990s, the multiplex model entered in Brazil, with companies such as Cinemark and UCI, which further promoted the entrance of American cinema, leaving Brazilian films to art house theaters, DVD's and cable TV. That is why going to the movies came to confer social status, because the tickets were more expensive. North American films gave prestige to those who watched them. Therefore, with the reduction of social inequality, during PT's government, the population managed to obtain power and the multiplex became part of people's daily life. Still, GloboFilmes, linked to RedeGlobo, also invested heavily in national cinema, having great financial returns with the production of family comedies, as well as the film production of several filmmakers, with the help of the government, of social films, with realistic clothes, that gained space and legitimacy in the circuits of festivals and awards, such as Central Brazil, City of God, Aquarius, etc.

\section{The Horror Arrises}

This historical survey illustrates the reason why I became interested as I found a peculiar literary phenomenon, linked to the national cinema, which began to appear in the passage from 2015 to 2016 and is consolidating in 2017. In my master's research, I wrote a continuing dissertation of studies initiated at the Federal University of Bahia on Pop Literature. Hoisel (1980) states that pop literature is "the meeting point between cultured art and mass communication, promoting the substitution of noble themes of traditional art for images of 
modern urban life, from the proposition of an aesthetics of consumability” (pp. 134-135). Thus, this discourse appropriated the urban image and fragmented together with the iconic objects and the imaginary of a culture of mass consumption to denounce the mass media in a critical posture, desacralising art in its hypertext of references.

Because of this research, I began to map, since 2012, writers of contemporary literature, who published from the 2000s, until then, little studied, to understand what kind of literature it was, how they read the contemporary and what market impact the inserted (?). Thus, from the work before my own, I was able to map several writers, mostly young ones, who were included in this list, such as LourenzoMutarelli, Ana Guadalupe, Clara Averbuck, Simone Campos, Antonio Xerxenesky, Raphael Montes, and Santiago Nazarian. Most of these writers, with a few exceptions and peculiarities, inhabit the inter-locus of legitimating criticism and bestselling culture, transposing, and circulatingboth in content and reception, between mass culture and scholarly academic culture, unable to compete with national and international bestsellers.

What happened from 2015 up to now, December 2017, in the writing of this work, was an investment in literature called "Post-Horror", from the publication of three novels by three writers, Secret Dinner (2016) by Raphael Montes, Neve Negra (2017) by Santiago Nazarian, and As Perguntas (2017) by Antonio Xerxenesky, by Brazil's biggest publisher, A Companhia das Letras. And in July 2017, the investment in the image of the artists, each with their own profile, and the concern of the publisher, the agents and the writers themselves, in the dissemination of this new literature that was emerging in Brazil was overwhelming. Several book reviews were published in the main newspapers, tables were held on the subject at the São Paulo and Rio de Janeiro Biennial Book and at several literary festivals. In addition to that, regarding the very form of reviewing the growing number of national horror films, there have been a number of publications and critics selling the films as such, including a post-horror film festival with national and international titles such as Neighbouring Sound, Get Out, Personal Shopper, The Witch - A Folkstale Story, O Rastro, in September 2017.

Raphael Montes, Santiago Nazarian and Antonio Xerxenesky, even flirting with horror, never characterized themselves as writers of the genre; on the contrary, they sought to speak of the police text, more generally accepted, or they said to write Pop Literature, mainly after the publication of articles on the subject. Raphael Montes is the least privileged by the critics, but the most successful on the financial aspect, and he also worked as a screenwriter on several large projects and with acclaimed directors. Santiago Nazarian and Antonio Xerxenesky are at the border between the two poles of legitimation, working with elements of pop culture critically, although they have already won literary prizes and are published by prestigious publishers. In 2014, with the publication of Biofobia of Santiago Nazarian and Perfect Days of Raphael Montes, and the joint participation of the two writers in literary events, I began to perceive a movement to strengthen the literature of gender.

In 2016, I attended the São Paulo Book Biennial to see the talk between Santiago Nazarian and Raphael Montes. During the meeting, the writers tried to think about the reason why there wasn't a tradition of the police and horror genres in Brazil. They problematized the unilateral way of seeing the genre literature only as a popular appeal, rejected by critics because it has a juvenile aspect. It was interesting to hear that their influence came from horror cinema. Both spoke of the recognition that Coffin Joe received abroad and his treatment as a joke in Brazil, exemplifying the prejudice and lack of knowledge about the genre. Simultaneously, the writers talked about how horror films and the Brazilian thriller were gaining ground, having several national productions, such as the Wolf 
at the Door (2013) and Neighboring Sounds (2012). The cinematographic production of horror in Brazil has gained legitimacy, mainly when observing the number of productions and their representatives in prizes and festivals. In my opinion, this denounces the interest of the writers and the publisher in producing and publicizing the genre.

The developer of the Nova Roma College in Recife, Gabriel Machado Bandeira, who develops a research on the possibility of predicting scores on sites such as the IMDB through data collection, used open-source codes from The Internet Movie Data Base github to collect the amount of Brazilian horror films produced throughout history for the present article. These data will be presented on the following graph:

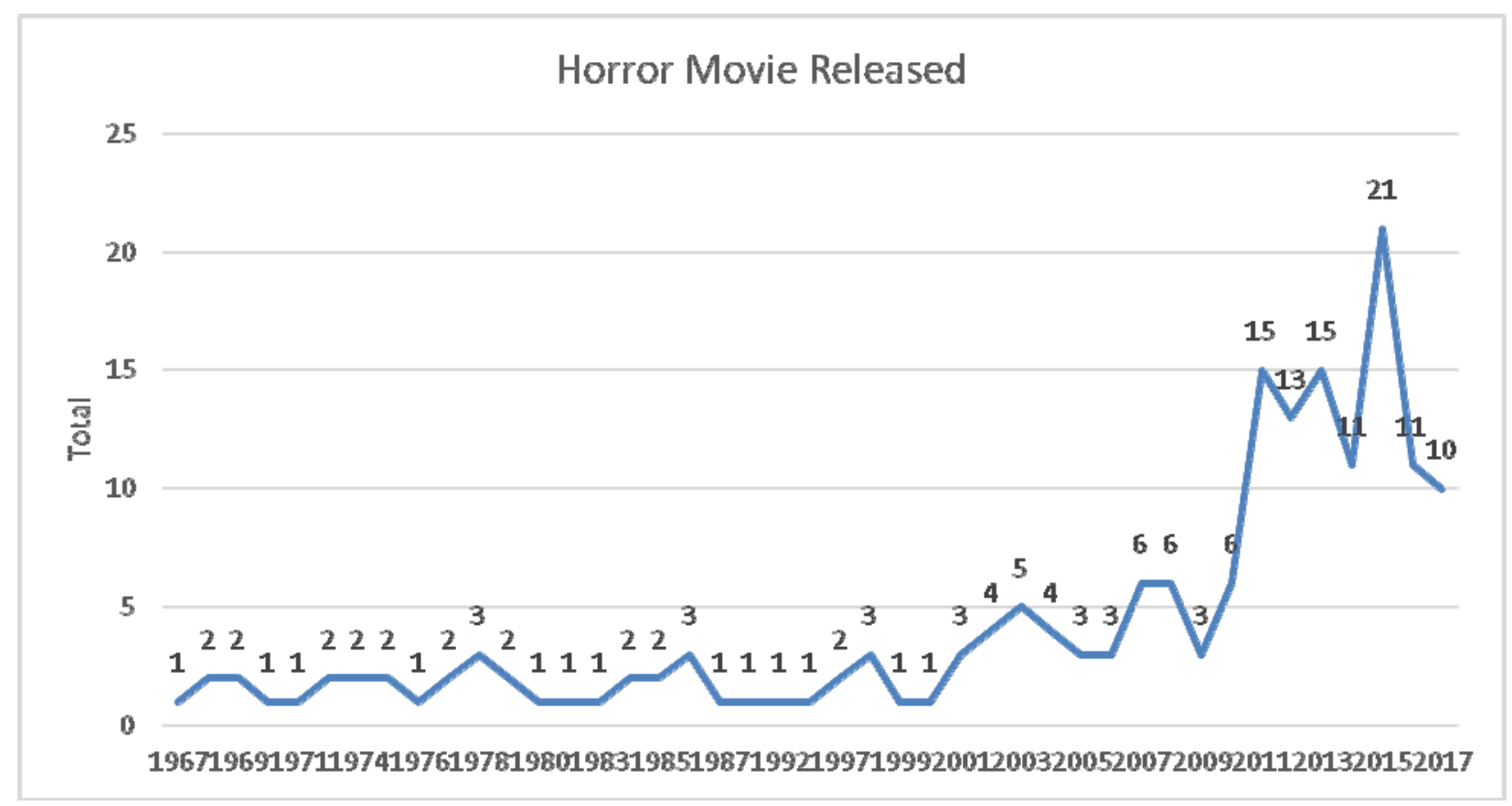

Figure 2. Brazilian Horror Films Released per Year.

The chart shows an exponential growth in the number of horror movies produced per year. From the second decade of the twenty-first century, when the programs for the promotion of the audiovisual sector were at their peak, under President Dilma's government, there was a growth in the overall amount of films produced, reaching the maximum in 2016 with 143 films. What is interesting about these data is that, in 2011, 15\% of the films produced were of horror. An inaugural landmark for the genre, since previously the release of horror films was proportional to the growth of the country's own film production.

The number of such films in 2015, for example, would justify publishers' interest in investing in horror, and although that peak has not been repeated and there is a decline in the production of national horror, the genre is increasingly gaining more prestige in festival circuits, such as Neirboring Sound (2012), which won the category of best film at the São Paulo International Film Festival, the Rio and Gramado Festival, the Polish Film Festival, the Copenhagen International Film Festival, the Serbian Film Festival and the Toronto Critics Association, as well as the critics' award at the International Film Festival in Rotterdam. In 2015, we had The Witch-A Folktale Story, a Brazilian production by RT Features and distributed by A24, which won Best Sci-Fi / Horror Movie at the Critics Choice Awards, Best First Screenplay and Best First Feature at the Independent Spirit Awards, and 
Directing Award at the Sundance Film Festival, for example. In 2017, Good Manners won the Rio Festival and the Locarno Film Festival as best film, and also participated in the symposium of several festivals such as the BFI London Festival and the AFI Festival here in Los Angeles.

\section{The Post-Horror Label}

Both The Good Ways and The Witch, for breaking the expectation of the jump scare and the stereotypes of horror, were classified as post-horror. In June 2017, The Guardian published the following article, "How post-horror movies are taking over cinema." In the text, Steve Rose criticizes the crystallized stereotypes of horror movies, which, based on the idea of the genre, should not allow this type of marketing model. Starting from this premise, Rose elects horror films from the past few years that transit well in the circuits of festivals and awards. These are: It Comes At Night (2017), The Witch: A New-England Folktale (2015), Personal Shopper (2016), Get Out (2017), A Ghost Story (2017) and The Neon Demon (2016). To him, what all these films have in common is the breaking of the formula of horror, going beyond that, as well as having an aesthetic acuity and a density of content and development of the characters.

The Post prefix serves to legitimize the taste for the recently produced horror films, qualifying them as better, outside the "disposable" structure of commercial horror movies. Thus, engaging and psychological horror "is worth it". It is this horror that is being awarded at festivals and enshrined by critics. Thus, after the text of The Guardian, the Brazilian media began to disclose Brazilian films as Post-Horror, as well as the books As Perguntasand Neve Negra. Both were unanimous among the journalistic and academic critics, and already generated the workshop The Weekend of Horror, organized by Cassia Carrenho, a great organizer of literary festivals, along with IllanaCasoy, Raphael Montes, and Santiago Nazarian. The authors of those two novels created a program on Radio da Companhia das Letras, the podcast of the publisher. The guests of the podcast are always important figures who bring prestige to the publisher, such as Caetano Veloso and Milton Hatoum. For this reason, making a podcast about Horror with both authors and the publisher, Rita Mattar, is a legitimizing strategy. Unsurprisingly, most of the questions sought to induce the discussion of how As Perguntas and Neve Negra were different, as they broke with the genre stereotypes.

And in a kind of informal conversation, Santiago Nazarian (2017a) says: "We should prove our books as post-horror", emphasizing that they would be "the first Brazilian books of post-horror". Then the publisher, Rita Mattarasks the authors to explain the term and why the books would be post-horror and, they play, Get Out and The Witch are the great examples of that. Xerxenesky questions the term by saying that The Dawn of the Living Dead in the 1980s already worked on racial issues, but then Nazarian says that the best example is The Witch, adding the following: "We need to speak well of The Witch and of Rodrigo". This post-horror strategy was commented on by Santiago Nazarian and Xerxeneskyduring interviews conducted by me in November 2017. In their conversation, the authors revealed that RT Features and A24 (as a distributor), which led to the critical success of The Witch, made Rodrigo Teixeira, owner of the production company, buy the rights to Biofobia and F., previous novels by the writers, and commissioned two more novels of horror, buying the right to adapt them. So when I asked Santiago Nazarian what finally led him to write a book of the horror genre, he replied: "I have always fed a lot of this culture - trash or not so trash, from the most terrifying horror to psychological horror; it is my genre” (Nazarian, 2017b). He continues: "For this reason, I have always tried to go further, bringingother 
references-more literary-the existentialist question” (Nazarian, 2017b). In his opinion, Neve Negra was the opportunity to do so.

"Product of an order from RT Features, a Brazilian production company that has in its curriculum films like the American 'The Witch', among several others. They wanted authors of Brazilian literature who could work horror with consistency. It was the opportunity for me to write a book admittedly of horror, already with a contract behind, a great publisher (Companhia das Letras). It was something I wrote specifically for this order “(Nazarian, 2017b).

When I asked about the move to Companhia das Letras, Brazil’s biggest publisher, he replied: “The migration to the Company came spontaneously because the book was an order from RT Features, which has a contract with them - the invitation from RT Features was that I would launch the book with the Company" (Nazarian, 2017b). In the perception of the author, the books published by that publisher are receivedmore warmly, contributingto the invitations to attendmore events, which became rarer after the cut on cultural investments.

Antonio Xerxenesky, during his interview, talked about how his academic life influenced his writing, mainly for having a literary project to write something pop (?). When I asked about the project to transform F., his second novel, a kind of homage to Citizen Kane, into film, Xerxeneskyreplied: “About the process, it was something simple: I met Rodrigo Teixeira, he liked the story of F, and bought the book. RT is breaking down many barriers and producing excellent films abroad. Their project is to carry out F outside Brazil” (Xerxenesky, 2017). "The order was quite open — there was a minimum of characters (150,000), a genre (horror) and a deadline. Oh, and a request to write something "filmable", that is, no spacecraft en route to Mars or poetic prose around the navel "(Xerxenesky, 2017). What he reports is that the book eventually became highly autobiographical, as an exercise, mainly because he had already worked with elements of horror before, even if never specifically with the genre. In the end, I asked about the post-horror label and he replied: "Post-horror is often used to say 'it's a horror movie but people who are not horror fans will also like it”” (Xerxenesky, 2017) and denounces the advertising logic behind his book: “This post-horror story can be useful in describing various works-even my book-but which I avoid using [...] are problematic labels, prejudicial, but useful for commercial/advertising purposes “(Xerxenesky, 2017).

After the interview, I understood that, boosted by the critical and productive success of national horror films, mainly from The Witch, and also from Raphael Montes’ young and very consuming audience, Rodrigo Teixeira, producer, director and creator of RT Features, has invested in this project of writers who transit between academic criticism, literary festivals and the public, believing that this would give legitimacy, both in the field of literature and in the field of cinema. While trying to schedule an interview with Rodrigo Teixeira, I received the following response: "Rodrigo has his schedule full by March” So, who are Rodrigo Teixeira and RT Features that are investing in horror movies and literature?

RT Features, from the initials of its founder, Rodrigo Teixeira, is the producer of Call me by your name (2017). The film tells the love story between two men in a summer in Italy and has won the award for best film at the Gotham Independent Film Awards and at the New York Film Critics Awards, and adapted screenplay at the Oscars. In 2016, The Variety published a report praising the achievements of the independent film production company titled “Brazil’s RT Features Give U.S. Independent Films a Boost”. 
Rodrigo Teixeira’s Brazil-based RT Features has produced Sundance hits “Indignation” by director James Schamus and "Little Men” by Ira Sachs. RT has developed work with Noah Baumbach ("Frances Ha," "Mistress America”), Kelly Reichardt (“Night Moves”), Sachs (“Love Is Strange”), Robert Eggers (2015 Sundance award-winner “The Witch”) and Gaspar Noe (Cannes competition player “Love”)” (Hopewell, 2016)

The producer also has a partnership with Martin Scorcese to produce new independent films, which this year was the acclaimed The Ciambra (2017), as well as Patti Cake \$ (2017), nominated for the Independent Spirit Awards. Teixeira also has an Oscar for leading the production team of Martin Scorsese's Hugo special effects.

In December 2017, Rodrigo Teixeira was interviewed by Veja Magazine, where he talked about his Rock Star routine in the Oscar campaign. The producer says, in a kind of silly cinematic narrative, that he takes pleasure in this whole process because he does it "for love" and chooses the projects that speak to his heart. The interesting part of the interview is how he describes his way of thinking and producing, as if it were the best of both worlds, because he thinks artistically as a Brazilian, that is, a vanguard thought, but does business as an American, reproducing common sense of the mutt complex.

I havea different market logic. And another thing I do is studying movies every day. Producing movies is not just about figuring howyou're going to raise the money and make the movie. You have to read about movies, watch a lot of movies, study how movies were made in the past, find possible references to get you up to speed (?) on future trends - I think that's the producer's job. Approaching young people, understanding what the young person is looking for. I am very happy because these three films communicate a lot with young people. I'm a 40-year-old guy; I'm entering the second part of my life. I can communicate with the young audience. It's something that interests me deeply. (Teixeira, 2017)

During an interview for the site Papo de Cinema, Ricardo Teixeira says that when he went to the United States to work with cinema, he only had \$ 500 and used \$ 100 to print his resume. However, his career only took off when he, working in an agency, recomended a manuscript that later became an international hit. Therefore, Teixeira says that he likes to invest in literature and comics since these always give good stories. One of the first successes of RT Features was the film O Cheiro do Ralo inspired by the work of the same name by Lorenzo Mutarelli. He also bought the rights to Tim Maia's Biography before it was written, which turned into a film in 2014. In an interview with Folha de São Paulo in 2011, Teixeira is described as "a kind of shareholder of literature. Where a critic sees a masterpiece, he sees a good deal. Where an author sees an idea, he sees a possibility of profit” (Cadouro, 2011). The text reveals how the producer has consolidated himself in the market as a negotiator of works for adaptation in national and international cinema.

In the article, he says that he bought the biography of Tim Maia for 180,000 reais and his company had at the time the rights of adaptation for at least 30 years. Teixeira uses the Rouanet Law for the production of the films and invest in book projects, but not for the acquisition of rights, and in its lobby of investors, like the businessman, Eike Batista, from the Universal Church of the Kingdom of God. The producer tells the story of the book "The Marriage of Romeo and Juliet" (2005), an entertainment book: "I paid R \$ 20,000 and sold it for R \$ 80,000. I saw that this was what I wanted to do" (teixeira, 2011) and he continues to talk about how the author buys rights to works for low prices and then sells them at higher prices. Teixeira was also widely criticized for the Amores Expressos Literary project, which used the Lei Rouanet to send consecrated writers, such as Chico Buarque, to different parts of Europe for a month, and from that experience, they would write a book which rights belonged to RT Features. In a interview in 2012, Texeira exposes his thoughts about the investment on Brazilian literatura what may wxplain why he is interested on this niche literature, that can be 
cheaper: "You have book rights in the US that you pay \$ 20,000 for the option, and you have a book in Brazil that sells for \$200,000. Best seller or not. For five years I believed in the Brazilian copyright market, I valued this market, I admit, but it was expensive. I've been asking myself a lot about this. The value of copyright in Brazil must be much lower for everyone to earn money” (Teixeira, 2012).

\section{The Transmedia Contruction of an Author}

From this, I believe that the concept of transmedia can be used to think about the phenomenon described so far. Henry Jenkins, from an analysis of the Matrix franchise, states that the term can be used to think of the marketing strategy of creating narratives that are completed as a whole, within a franchise, a brand, in order to maintain its consumer active, interested and satified. In this sense, Jenkins states: “A transmedia story unfolds across multiple platforms, with each new text making a distinctive and valuable contribution to the whole. In the ideal form of transmedia storytelling, each medium does what it does best-so that the story could be introduced in a film, expanded through television, novels, and comics; its world might be explored through game play or experienced as an amusement park attraction” (Jenkins, 2006, pp. 95-96). The concept is widely used in the field of audience studies and fans, however, in this work I would like to think of transmedia as a strategy for building the figure of the author, from the production of a media and not after its existence.

After all, the books are published linked to the publicity of a new genre, in the idea that they will be transformed into other media. The advertising of this genre, post-horror, is made in a transmediatic way. What is being marketed is the symbolic value of the genre, signaling Raphael Montes, Antonio Xerxenesky and Santiago Nazarian, and Rodrigo Teixeira himself, as the vanguard of Brazilian artistic production. Ramon Lobato (2010) states that "genre is understood to construct a movie's 'narrative image' which is communicated by industry to industry before a movie's release (ie by the producers or studio to distributors, exhibitors, marketing departments, etc.), to the press, and eventually promoted to an audience” (Lobato, 2010, p. 4). By placing the prefix "post", referring to postmodernity or post-structuralism, it adds a semantic idea of high level aesthetic, re-signifying a genre discredited. However, different from what Lobato postulates, in the case in question, the genre is not only defining a film, it is defining a production and an authorship project.

Thus, it is necessary to think of the figure of the author. Michel Foucault discusses the idea of constructing the author's name. To him, the author does not function as a proper name. The name does not equate to the individual that it designates, but rather to a kind of brand and filiation. The example between the proper name and the individual that it designates has more functions besides just indicating them and the relation between the author and what he names-it relates to a work, the construction of the text. The fact that the texts are grouped under the same name indicates homogeneity. The name indicates that it is not a daily speech, but a discourse that must be received in a certain way, in a certain culture with a certain statute. The author's name characterizes the texts and establishes a set of discourses, his unique way of saying, not necessarily related to the fiction of the work. Thus, Foucault (1999) states: "Finally, the author's name characterizes a particular manner of existence of discourse. Discourse that possesses the author's name is not to be immediately consumed and forgotten; neither is it accorded the momentary attention given to ordinary, fleeting words. Rather, its status and its manner of reception are regulated by the culture in which it circulates” (p. 452). 
The author is what allows us to explain both the presence of certain events in a work and its transformations. The author is also the principle of a certain unity of writing, so all differences are reduced by the principles of evolution, maturation or influence. The author's speech composes a plurality of self, and thinks of the subject as multiple in its various positions, personas and performances. Thus, the author's name is a construction of legitimacy, a sign of grouping and symbolic power. Eneida Maria de Souza (2002), within the contemporary Brazilian literary context, affirms that the author, in order to survive, seeks to insert himself in the spaces of legitimation—academic literary criticism and the consumer market—or both, in an attempt to construct Your Author Name. For Eneida, the proliferation of discursive practices considered "extrinsic" to literature, such as mass culture (such as cinema), biographies, and everyday events. The writers, in order to enter the market (both critics and bestsellers), seek to navigate through all these points, being attentive to the reception of their works as a way for their production and for their performance as a writer.

Paula Sibllia (2016) uses the term "hypertrophy of the self” to make a reflection on the spectacularization of the subject. In her opinion, we have been living the era of branding. The subject becomes a brand that needs to be managed. They care about their logo, their visual identity and their effective discourse to influence and capture several other users who also capitalize or produce themselves in that way of life. Paula Sibilia discusses these personal strategies of screen display and consecration of an image, seeking to denounce how the behavior of display on the network has come to play a fundamental role in everyday life in which everyone tends to publicize through a model of what is considered ideal. To her, the constructions of self are oriented from an external look that guarantees validation, trying to respond to the social and cultural demands of a society that demands the exhibition of the subject, who seeks legitimacy.

At this point, all three writers, in defending their literature as different, non-commercial, with aesthetic quality, use the term post-horror for being associated with a prestigious cinematic aesthetic, and are, at least for now, trying to build their author's name, to make a branding of the literary projects of each one. Although books are the design of an order, Santiago Nazarian and Antonio Xerxenesky defend them by saying that they are part of their literary project and their own aesthetic, trying, from the construction of what his brand names mean, to include something that was made by the need for survival in the field of very arid literary art for a writer who stands at the border between the commercial and the academic scene. Raphael Montes, who works with cinema, is more interested in the term, because it is not only his literature that can be sold post-aesthetic-commercial common, but also his work with cinema, which already has partnerships with great directors of the national cinema.

However, there is a construction of the author name Rodrigo Teixeira through RT Features. As a literature lobbyist, by purchasing adaptation rights and selling them at a more expensive price, Teixeira is built as a vanguard, for knowing before-hand what will be desired in the future. By wrapping books and appropriating the post-horror term produced by RT Features in partnership with A24's distribution, Texeiratrans forms its wild capitalism into an art business, branding RT Features as the new salvation of indie cinema in the world, after all there is a partnership with Martin Scorcesse, who will probably run for the Oscar with Call me by your name.

In this process of constructing the name of an author, there is a mystification of the meritocracy of the self-made man. He tells the story of someone who won all this cultural appreciation because he struggled in a personal battle, hiding his place of privilege. In the end, Rodrigo Teixeira, by scrapping and unequally paying 
Brazilian writers, devaluing creativity and profiting from the misery of the artistic circuit, is constructing the symbolic capital of RT Features, his author's name, in the midst of the circuit of festivals and awards. My bet for the next few years is that we will see a trend of contemporary Brazilian writers being "inspired" by Call me by your name.As a readerand a researcher, I'll be waiting. Until them, I will be Reading a lot of stories with the themes os the Post-Horror, canibalism, satanism, demoniac bunny`s and the Biophobia of being a artist in a material and simbolic market.

\section{References}

Autran, A. O. (2011). Cinema Brasileiro Contemporâneo diante do público e do mercado exibidor. Jornal Significações, 32, 119-136.

Cortina, A. (2014). Perfil do leitor brasileiro contemporâneo: os livros mais vendidos no Brasil de 1966 a 2010. Campinas: Mercado das Letras.

Faz, R. (2011). O Acionista das Letras. Retrieved from https://www1.folha.uol.com.br/fsp/ilustrad/fq1101201110.htm

Foucault, F. (1991). What is an Author? Rethinking Popular Culture (pp. 446-464). UC PRESS.

Genestrete, G. (2017). Crítica vê surgir gilmes sem susto fácil: o pós-terror. A Folha de São Paulo. Retrieved from http://www1.folha.uol.com.br/ilustrada/2017/07/1902643-critica-ve-surgir-filmes-sem-susto-facil-o-pos-terror-cineastas-reag em.shtml

Gois, A. (2016). Jantar Secreto de Raphael Montes Vai Virar Filme. O Globo. Retrievedfrom http://blogs.oglobo.globo.com/ancelmo/post/jantar-secreto-de-raphael-montes-vai-virar-filme.html\#comments

Hoisel, E. (Ed.). (1980). Supercaos: os estilhaços da cultura em Panamérica e Nações Unidas. Rio de Janeiro: Civilização Brasileira.

Hopewell, J. (2016). Brazil's RT Features Give U.S. Independent Films a Boost. The Variety. Retrieved from http://variety.com/2016/film/global/brazil-production-company-rt-features-1201701634/

Jenkings, H. (2006). Convergence cultura where old and new media collide. New York: New York University Press.

Lobato, R. (2010). Rethinking genre studies through distribution analysis: Issues in international horror movie circuits. Retrieved From http://www.tandfonline.com/doi/abs/10.1080/17400309.2011.556944

Montes, R. (2016). Secret dinner. New York: Penguin.

Morisawa, M., (Interviewer) \& Teixeira, R. (Interviewee). (2017). Brasileiro em Campanha pelo Oscar "Me Sinto em uma Turnê de Rock”. Veja. Retrieved from

https://veja.abril.com.br/entretenimento/brasileiro-em-campanha-pelo-oscar-me-sinto-numa-turne-de-rock/

Nazarian, S. (2017a). Neve Negra. São Paulo: Companhia das Letras.

Nazarian, S. (2017b) Pesquisa Informal mostra que poucos escritores se sustentam pela venda de livros no Brasil. A Folha de São Paulo. Retrieved from

http://www1.folha.uol.com.br/ilustrada/2014/12/1567614-pesquisa-informal-mostra-que-poucos-escritores-se-sustentam-pela -venda-de-livros-no-brasil.shtml

Reis, R. (1992). Cânon. Rio de Janeiro: Imago.

Ristow, F. (2016). A quatidade de Filmes Nacionais lançados no cinema ano a ano. O Globo. Retrieved from http://infograficos.oglobo.globo.com/cultura/a-quantidade-de-filmes-nacionais-lancados-no-cinema-ano-a-ano.html

Roberto, M. (Interviewer) \& Teixeira, R. (Interviewee). (2016). Papo de Cinema. Retrieved from https://www.papodecinema.com.br/entrevistas/rt-features-entrevista-exclusiva-com-rodrigo-teixeira/

Rose, S. (2017). Post Horror Films are taking over. The Guardian. Retrieved from https:/www.theguardian.com/film/2017/jul/06/post-horror-films-scary-movies-ghost-story-it-comes-at-night

Sibilia, P. (2016). O show do eu: intimidade como espetáculo. Rio de Janeiro: Contraponto.

Souza, C. R. (2007). Raizes do Cinema Brasileiro. Jornal of Pioneiros do Brasil no cinema, 8, 20-38.

Souza, E. M. (2002). Crítica Cult. Belo Horizonte: Editora UFMG.

Tomazonni, M. (interviwer) \& Teixeira, R. (Interviewee). (2012). Rodrigo Teixeira, o Infiltrado em Hollywood. Retrieved from https://ultimosegundo.ig.com.br/cultura/cinema/2012-04-27/rodrigo-teixeira-o-infiltrado-em-hollywood.html

Xavier, I. (2001). O Cinema Brasileiro Moderno. São Paulo: Paz e Terra.

Xerxenesky, A. (2017). As Perguntas. São Paulo: Companhia das Letras. 